\title{
The Decision Support System for Hierarchical Portfolio Management
}

\author{
Pradit Songsangyos, Member, IACSIT
}

\begin{abstract}
Securities investment in the capital market is one of the key factors in the socialism economic system.In order to optimize the return on investment, investors will build portfolio of their securities. The decision support system is intentionally developed for investment to select the securities in the Thai stock market, from a properly diversified stock portfolio, by using multi-criteria decision making technique. The hierarchical methods like AHP make complex decisions become easy make it easy in multi-criteria chosen. The system lets the user to create a rating for each criterion, calculates a relative weight to each criterion and then ranks securities listed on the stock market. Finally, the top rank security are collected to the portfolio. For further study, a decision support system for the capital investment planning and analysis to resolve, how much securities, bonds, gold, properties, and cash in hand needed to be invested, will be developed.
\end{abstract}

Index Terms-AHP, decision support system, portfolio management, multi-criteria selection.

\section{INTRODUCTION}

Securities investment in the capital market is one of the key factors in the socialism economic system. The enterprises are generally looking for the opportunities to expand in the condition of economic growth. Financial system can trigger off the growth in capital markets through issuing stocks and bonds. Investors or decision-makers monitor the changing of the capital market and environments via the economic, the monetary, the political, and the psychological forces. In this sense, they need to have enough data and information which are most accurate and up-to-date [1].

In order to optimize the return on investment, investors will build portfolio of their securities. The efficient portfolio can only be acquired when the stocks in the portfolio show negatively correlated investments. Thus, the securities selection in the portfolio should not be based from only one industry because of their tendency to correlate strongly positively [2]. For portfolio management, if an investor or decision maker invested in greater than or equal to 15 securities then the system risk will be diversified to give a total systematic risk of portfolio equal to zero. Investors or decision makers must seek to earn the optimum profit by selecting some securities with high return, continuous growth rate, and acceptable minimal risk [3].

Decision support system is a computer system designed to help decision-makers improve decision making. They can be defined as an approach to effective decision making

Manuscript received September 14, 2013; revised November 16, 2013. This work was supported in part by the Rajamangala University of Technology Suvarnabhumi.

P. Songsangyos is with the Computer Science Department, Rajamangala University of Technology Suvarnabhumi, Pranakhonsiayutthaya, Thailand (e-mail: spradit@rmutsb.ac.th). involving an interface between the individual and computer, from problem formulation to solution [4].

The proposed decision support system is developed for investment decision-making to select the securities in the Thai stock market, from a properly diversified stock portfolio. The multi-criteria selection which is applied to optimize the return on investment is financial ratio including: operating profit margin, debt to equity, price earnings ratio, and price to book value. The measurement of these ratios is usually used for indicating the performance of the enterprises. An interactive computer-based system includes three major parts: database; model base; and user interface.

\section{LiteratURE REVIEW}

\section{A. Analytical Hierarchical Process (AHP) Method}

Very frequently, when analyzing a problem, the amount of entities and their multiple relations increase beyond the ability of people to understand the problem as a whole. In these situations hierarchic methods like AHP make it easy and bring advantages. In modeling, the goal, the alternatives and criteria are chosen, forming the hierarchy. A hierarchic tree structure is presented in Fig. 1.

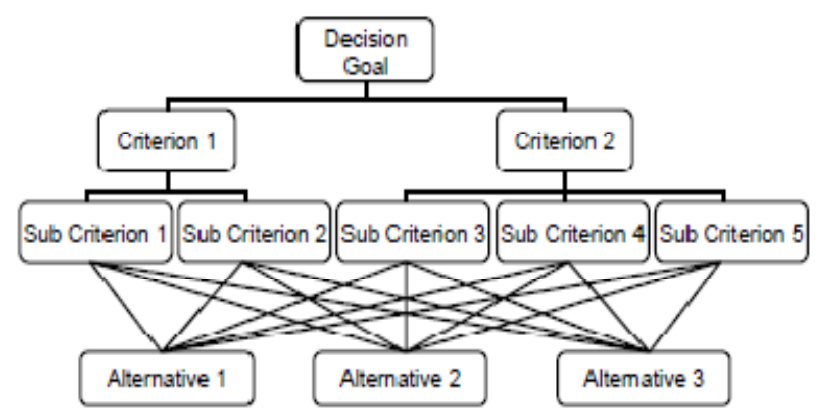

Fig. 1. Example of 4 levels decision hierarchic structure [4].

Structure must be homogeneous and non-redundant. The AHP is based on pairwise matrixes with lines and columns corresponding to factors. The use of pairwise matrix with inconsistent degree of less than $10 \%$ is generally acceptable [5]. When a matrix presents a degree of inconsistency higher than $10 \%$ review is suggested in order to find possible evaluation errors, typing errors or bad interpretation of the criteria or alternatives involved. It is possible to evaluate the whole matrix or just some its values, or even dismiss the responsible for the evaluations, substituting him for other who can assign more consistent value [6].

To make a decision in an organized way to generate priorities we need to decompose the decision into the following steps.

1) Define the problem and determine the kind of knowledge sought. 
2) Structure the decision hierarchy from the top with the goal of the decision, then the objectives from a broad perspective, through the intermediate levels (criteria on which subsequent elements depend) to the lowest level (which usually is a set of the alternatives).

3) Construct a set of pairwise comparison matrices. Each element in an upper level is used to compare the elements in the level immediately below with respect to it.

4) Use the priorities obtained from the comparisons to weigh the priorities in the level immediately below. Do this for every element. Then for each element in the level below add its weighed values and obtain its overall or global priority.

Continue this process of weighing and adding until the final priorities of the alternatives in the bottom most level are obtained [7].

\section{B. Analytical Hierarchy Process in Security Selection}

Tarmizi stated in [2] that, the security selection process is done by applying some objective criteria, which are those commonly used to measure the company performance. Those criteria are seven financial ratio analysis, which are current ratio, acid test ratio, operating profit margin, debt to equity, return on equity, price earning ratio, and price to book value. Arifin then used analytical hierarchy process (AHP) method for ranking the securities in Indonesia coal industry by multi-criteria as mentioned above. The study found that, the test of consistency shows consistent of four ratios including: the Operating Profit Margin, the Debt to Equity Ratio, the Price to Earning Ratio and the Price to Book Value.This means that all respondents give the relatively homogenous responses in using those four ratios to rank the securities in coal industry. It can also be concluded that those four ratios can provide important information value to be a useful criteria in ranking the securities. For the other three ratios, the test of consistency result is not consistent. This means that respondents have heterogenous responses in using those ratios to rank the securities. Therefore,those three criteria cannot become measurement criteria.

\section{Methodology}

\section{A. The Sorting Process}

From a study of Arifin, he found that the seven financial ratios used as criteria to rank the securities in coal industry provide inconsistent results. The test of consistency shows consistent of four ratios. While the other threeratiosis inconsistent. In addition, $\mathrm{Li}$, et al. suggested that it is possible to evaluate the whole matrix or just some its values. So this study used those four criteria which are consistent as mentioned above to ranking the securities. The Between criteria from four financial ratios including: the Operating Profit Margin, the Debt to Equity Ratio, the Price to Earning Ratio and the Price to Book Value, is 0.0578 as shown in Table I. Therefore, the four criteria to rank the securities in coal industry provide consistent results.

So this study used those four criteria as mentioned above for ranking the securities grouped by their industry. In modeling, the goal, the alternatives and criteria are chosen, forming the hierarchy as shown in Appendix.
TABLE I: THE CONSISTENCY RATIO FOR EACH MEASUREMENT CRITERIA (ADAPTED FROM [2])

\begin{tabular}{lcl}
\hline \hline Pairwise matrix & Consistency Ratio & Evidence \\
\hline $\begin{array}{l}\text { Stock selection with } \\
\text { Operating Profit } \\
\text { margin }\end{array}$ & 0.0664 & Consistent \\
$\begin{array}{l}\text { Stock selection with } \\
\text { Debt to Equity Ratio }\end{array}$ & 0.0713 & Consistent \\
$\begin{array}{l}\text { Stock selection with } \\
\text { Price to Earning Ratio }\end{array}$ & 0.0514 & Consistent \\
$\begin{array}{l}\text { Stock selection with } \\
\text { Price to Book Ratio }\end{array}$ & 0.0419 & Consistent \\
Between criteria & 0.0578 & Consistent \\
\hline \hline
\end{tabular}

\section{B. System Design}

An overview of the proposed DSS was used as a basis for the implementation as shown in Fig. 2. Microsoft Excel was selected as a tool to develop an application of the decision support system in developing hierarchical portfolio.

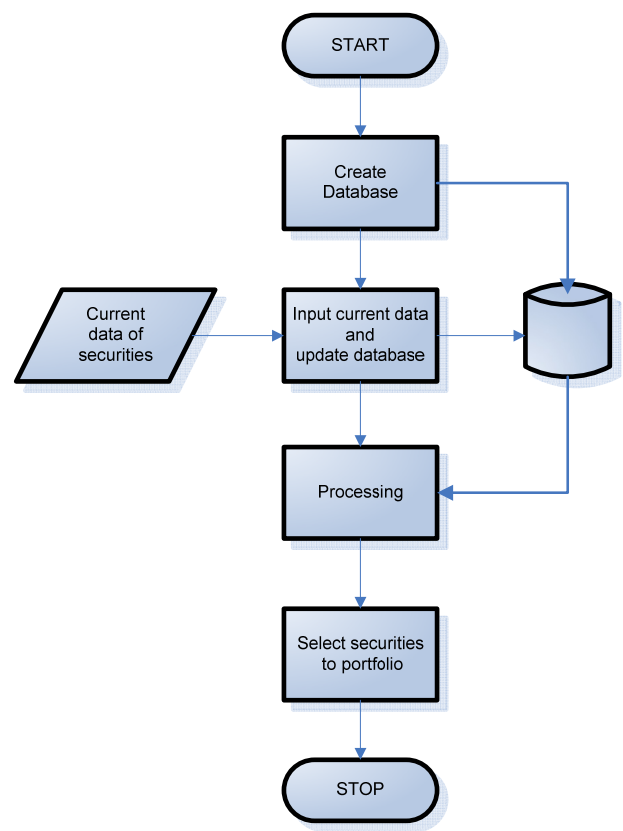

Fig. 2. Overview of the proposed DSS.

\begin{tabular}{llcccc}
\multicolumn{7}{c}{ TABLE II: DATA INPUT [8] } \\
\hline \hline \multirow{2}{*}{ Industry } & $\begin{array}{l}\text { Security } \\
\text { name }\end{array}$ & $\begin{array}{c}\text { Operating } \\
\text { Profit } \\
\text { Margin }\end{array}$ & $\begin{array}{c}\text { Debt to } \\
\text { Equity } \\
\text { Ratio }\end{array}$ & $\begin{array}{c}\text { Price to } \\
\text { Earning } \\
\text { Ratio }\end{array}$ & $\begin{array}{l}\text { Price to } \\
\text { Book } \\
\text { Value }\end{array}$ \\
\hline Bank & BAY & 30.8 & 1.36 & 13.912 & 1.7956 \\
Bank & BBL & 42.85 & 0.3976 & 12.3699 & 1.4933 \\
Bank & KBANK & 32.34 & 0.4725 & 14.053 & 2.6787 \\
Bank & KTC & 37.65 & 0.8135 & 12.5297 & 1.9774 \\
Bank & SCB & 35.92 & 0.6093 & 14.8774 & 2.7459 \\
Energy & BANPU & 20.64 & 1.26 & 10.8804 & 1.3077 \\
Energy & EGCO & 14.39 & 0.5332 & 7.4101 & 1.2062 \\
Energy & IRPC & 0.11 & 0.6287 & 14.8694 & 1.1018 \\
Energy & PTT & 6.87 & 0.7515 & 8.9247 & 1.5418 \\
Energy & PTTEP & 49.52 & 0.3522 & 8.5022 & 1.7363 \\
ICT & ADVANC & 32.99 & 0.3178 & 19.9478 & 16.0469 \\
ICT & DTAC & 17.79 & 0.8666 & 19.53 & 6.3043 \\
ICT & INTUCH & 175.22 & 0.3178 & 17.3811 & 11.0217 \\
ICT & JMART & 6.07 & 0.8197 & 23.125 & 9.8911 \\
ICT & THAICOM & 19.94 & 0.5136 & 52.2025 & 2.5078 \\
\hline \hline
\end{tabular}

The first step is to create the database structure. Next, the data such as Industry; Security Name; Operating Profit Margin; Debt to Equity Ratio; Price to Earning Ratio; and 
Price to Book Value are entered into a database as shown in Table II.

Next, the user can establish a rating scale for each criterion, a 9-point rating scale. Different users may have different aims for different types of criteria. For example, one may first look at operating profit margin while the others may look at the price-to-earnings ratio or other types of financial ratios.

The example of the desired rating scale is shown in Table III.

TABLE III: EXAMPLE OF THE USER DESIRED RATING SCALE

\begin{tabular}{lc}
\multicolumn{1}{c}{ Criteria } & Rating scale (1 to 9) \\
\hline \hline Operating Profit margin & 7 \\
Debt to Equity Ratio & 5 \\
Price to Earning Ratio & 8 \\
Price to Book Ratio & 4 \\
\hline \hline
\end{tabular}

Then the system calculates the weighting scale for each criterion $\left(W_{n}\right)$. The rating scaleis divided by a total score as shown in Table IV.

TABLE IV: EXAMPLE OF CALCULATED WEIGHTING SCALE

\begin{tabular}{lcc}
\multicolumn{2}{c}{ TABLE IV: EXAMPLE OF CALCULATED WEIGHTING SCALE } \\
\hline \hline \multirow{2}{c}{ Criteria } & Consistency Ratio & Evidence \\
\hline Operating Profit margin & 7 & $7 / 24=0.29$ \\
Debt to Equity Ratio & 5 & $5 / 24=0.21$ \\
Price to Earning Ratio & 8 & $8 / 24=0.33$ \\
Price to Book Ratio & 4 & $4 / 24=0.17$ \\
Total score & 24 & 1.0 \\
\hline \hline
\end{tabular}

Next, securities in the industry are ranked by operating profit margin from the highest to the lowest using a scale of 9 to 1 . Due to the memory capacity of the human brain, a scale of 9 to 1 is assumed to suit individual users' perceptions as Miller stated in [2]. The numerical values for operating profit margin of securities in the bank industry have shown in Table V.

TABLE V: EXAMPLE OF VALUE For OPERATING PROFIT MARGIN

\begin{tabular}{lcc}
\hline \multicolumn{1}{c}{ Security name } & Operating Profit Margin & Numerical value \\
\hline BAY & 42.85 & 9 \\
KBANK & 37.65 & 8 \\
SCB & 35.92 & 7 \\
KTC & 32.34 & 6 \\
BBL & 30.8 & 5 \\
\hline \hline
\end{tabular}

TABLE VI: EXAMPLE OF VALUE FOR DEBT TO EQUITY

\begin{tabular}{lcc}
\hline \multicolumn{1}{c}{ Security name } & Debt to Equity Ratio & Numerical value \\
\hline BBL & 0.3976 & 9 \\
KBANK & 0.4725 & 8 \\
SCB & 0.6093 & 7 \\
KTC & 0.8135 & 6 \\
BAY & 1.36 & 5 \\
\hline \hline
\end{tabular}

For debt to equity ratio, the lesser a ratio show the better performance, a negative value. So the securities in the industry are ranked by debt to equity ratio from the highest to the lowest using a scale of 9 to 1 . The numerical values for debt to equity ratio of securities in bank industry have shown in Table VI. In addition, the other two financial ratios such as price to earning ratio andprice to book valueshow negative values so that the ranks are the same as debt to equity ratio.

The system calculates the total score for each security in the industry by equation (1).

$$
\begin{gathered}
\text { Total }=\left(\text { Value }_{1} \times W_{1}\right)+\left(\text { Value }_{2} \times W_{2}\right)+\left(\text { Value }_{3} \times W_{3}\right)+\left(\text { Value }_{4}\right. \\
\left.\times W_{4}\right)
\end{gathered}
$$

The example of results has shown in Table VII.

TABLE VII: EXAMPLE OF CALCULATED TOTAL SCORE

\begin{tabular}{lccccc}
\hline \hline $\begin{array}{l}\text { Security } \\
\text { name }\end{array}$ & $\begin{array}{c}\text { Operating } \\
\text { Profit } \\
\text { Margin }\end{array}$ & $\begin{array}{c}\text { Debt to } \\
\text { Equity } \\
\text { Ratio }\end{array}$ & $\begin{array}{c}\text { Price to } \\
\text { Earning } \\
\text { Ratio }\end{array}$ & $\begin{array}{c}\text { Price to } \\
\text { Book } \\
\text { Value }\end{array}$ & Total \\
\hline BAY & 9 & 9 & 9 & 9 & 9 \\
BBL & 5 & 5 & 7 & 8 & 6.1667 \\
KBANK & 8 & 6 & 8 & 7 & 7.4167 \\
KTC & 6 & 8 & 6 & 6 & 6.4167 \\
SCB & 7 & 7 & 9 & 5 & 6 \\
\hline \hline
\end{tabular}

Then ranking securities in the industry by their total score from the highest to the lowest as shown in Table VIII.

TABLE VIII: RANKING BY SECURITIES' TOTAL SCORE

\begin{tabular}{lccccl}
\hline \hline Security & $\begin{array}{c}\text { Operating } \\
\text { Profit } \\
\text { name }\end{array}$ & $\begin{array}{c}\text { Debt to } \\
\text { Equity } \\
\text { Ratio }\end{array}$ & $\begin{array}{c}\text { Price to } \\
\text { Earning } \\
\text { Ratio }\end{array}$ & $\begin{array}{c}\text { Price } \\
\text { to } \\
\text { Book } \\
\text { Value }\end{array}$ & Total \\
\hline BAY & 9 & 9 & 9 & 9 & 9 \\
KBANK & 8 & 6 & 8 & 7 & 7.4167 \\
KTC & 6 & 8 & 6 & 6 & 6.4167 \\
BBL & 5 & 5 & 7 & 8 & 6.1667 \\
SCB & 7 & 7 & 9 & 5 & 6 \\
\hline \hline
\end{tabular}

\section{Analytical Hierarchy Process in Security Selection}

Finally, the top rank security in the industries were collected to the portfolio as shown in Table IX.

\begin{tabular}{cc} 
TABLE IX: TOP RANK SECURITY IN INDUSTRY COLLECTED TO PORTFOLIO \\
\hline \hline Industry & Security \\
\hline Bank & BAY \\
Energy & EGCO \\
ICT & INTUCH \\
\hline \hline
\end{tabular}

\section{CONCLUSIONS}

From a study of Arifin, he used seven financial ratios as criteria for rating securities. The test of consistency shows consistent of four ratios, while the others are inconsistent. So this study selected only four consistent financial ratios including: the Operating Profit Margin, the Debt to Equity Ratio, the Price to Earning Ratio and the Price to Book Valuefor ranking the securities. The between criteria from four financial ratios provide consistent results as well. The multi-criteria selection from four financial ratios as mentioned earlier is used to ranking the securities grouped by the industry in Thai stock market. By selecting some securities with a fairly high rate of return, proper diversification can reduce or eliminate systematic risk. In modeling, the goal, the alternatives and criteria are chosen to form the hierarchical structure. The user can establish a rating scale for each criterion, a 9-point rating scale. Then the system calculated the weighting scale for each criterion. The rating scale was divided by a total score. Next, securities in the industry were ranked. Lastly, the top rank securities in the industry were collected to the portfolio.

The investors may not be able to invest only in security market or one another. Making decisions can be difficult 
about how much securities, bonds, gold, properties, and cash in hand needed to be invested, etc. For further study, we will consider other decision making techniques in the capital decision-making process for investments.

\section{APPENDIX}

\section{A. Hierarchic Tree Structure}

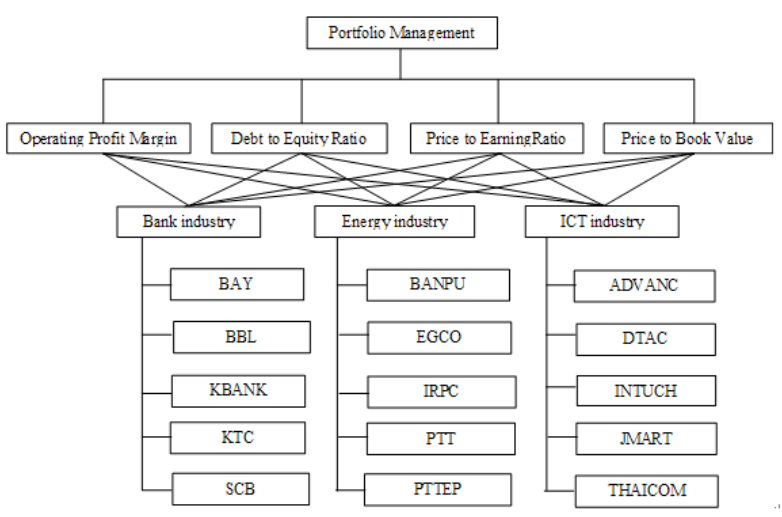

\section{ACKNOWLEDGMENT}

I wish to express my deep sense of gratitude to Dr. Nipat Jongsawat for his suggestions, and helped me in completing the research work, in time. Finally, yet importantly, I would like to express my heartfelt thanks to my beloved parents for their blessings.

\section{REFERENCES}

[1] J. C. V. Horne, Financial Management and Policy, $12^{\text {th }}$ edition, Prentice-Hall, 2002.

[2] A. Z. Arifin, "The Analytical Hierachy Process (AHP) Method for Stocks Rank," in Proc. Cambrige Business \& Economics Conference, 2011, pp. 1-26.

[3] Fischer and Jordan, Security Analysis and Portfolio Management, $6^{\text {th }}$ edition, Prentice-Hall, 1995.

[4] R. J. Thierauf, User-oriented Decision Support Systems: Accent on Problem Finding, Prentice-Hall, 1988.

[5] G. L. Torres et al., "Decision-Making using a paraconsistent Analytic Hierachy Process," in Proc. $5^{\text {th }}$ International Conference on European, 2008, pp. 1-6.

[6] Y. Li et al., "Multi-Criteria Sorting Method based on AHP and Variable Rough Set," in Proc. the 2011 International Conference on Machine Learning and Cybermetics, Xian, 2012, pp. 261-266.

[7] T. L. Saaty, "Decision making with the Analytic Hierachy Process," International Journal of Services Sciences, vol. 1, no. 1, pp. 83-98, 2008.

[8] Markets data. The Financial Times Ltd.. [Online]. Available: http://markets.ft.com/research/markets/companies-research

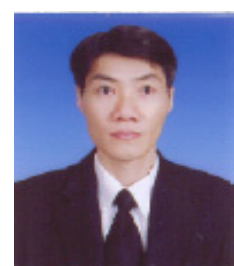

P. Songsangyos was born in Chiangmai, Thailand. He obtained his M. Eng, in information technology from Asian Institute of Technology, Bangkok, Thailand in 1997, and M.B.A. in management from Maejo University, Chiangmai, Thailand in 1999.

Currently, he is a head of computer science department, faculty of science and technology, Rajamangala University of Technology Suvarnabhumi. His research interested was focus on decision support system, and knowledge-based system which appeared as, "Automated Reference Services", Proceeding of International conference on computer technology anddevelopment, 2009,Kota Kinabalu, Malaysia. The Knowledge Management in Higher Education in Chiang Mai: A Comparative Review. Procedia - Social and Behavioral Sciences, vol. 69, 24 December 2012, pp. 399-403.

Mr. Songsangyos is a committee of Applied Computer and Information System Academic Network University since 2010-present. 